\title{
Urgensi Fatwa DSN-MUI Mengenai Manajemen Risiko Pembiayaan Berbasis Syariah
}

\author{
Tri Hidayati ${ }^{*}$, Muhammad Syarif Hidayatullah ${ }^{2}$ \\ ${ }^{1 *}$ IAIN Palangka Raya \\ Jl. G. Obos Kompleks Islamic Centre Kota Palangka Raya Provinsi Kalimantan Tengah \\ Email:tri.hidayati@iain-palangkaraya.ac.id
}

${ }^{2}$ UIN Antasari Banjarmasin

Jl. A. Yani Km. 4,5 Kota Banjarmasin Provinsi Kalimantan Selatan

Email: syarif.muhammad849@gmail.com

\begin{tabular}{llll}
\hline Submit & $: 19$ Maret & Diterima & $: 25$ Agustus \\
Revisi & $: 2$ November & Terbit & $: 1$ Desember 2021 \\
\hline
\end{tabular}

Abstract: Risk management at Islamic financial institutions is still implementing bank Indonesia (BI) and Financial Services Authority (OJK) policies which previously applied the same to conventional financial institutions. The perfection of the enforcement of sharia principles in sharia financing institutions is not enough only in the aspect of transactional mechanisms, it needs to be supported by a sharia-based risk management system. The focus of this research includes the characteristics of Islamic financing, juridical aspects in the principle of prudence, and an overview of the maslahah of the urgency of sharia-based risk management. This research is normative legal research using a statutory approach and a benefits approach with a qualitative descriptive analysis. The results of the discussion show that a dynamic system also needs to be supported by juridical aspects to provide the legal force with the realization of regulatory solidity. At this regulatory level, in addition to the regulations issued by the OJK, the DSN-MUI fatwa is also very necessary and has a very urgent position. Because financing risk management is also part of the sharia economy that must maintain sharia principles, lest the application of sharia principles only exists in product technicalities, but does not apply to technical risk management. The expected sharia is the application of total sharia principles (kaffah), not partial ones.

Keywords: DSN-MUI Fatwa, Risk Management, Sharia Financing

Abstrak: Manajemen risiko pada Lembaga Keuangan Syariah sejauh ini masih menerapkan kebijakan BI dan OJK yang sebelumnya berlaku sama pada lembaga keuangan konvensional. Kesempurnaan tegaknya prinsip-prinsip syariah pada lembaga pembiayaan syariah tidak cukup hanya pada aspek mekanisme transaksional, perlu didukung dengan sistem manajemen risiko yang berbasis syariah. Fokus penelitian ini meliputi karakteristik pembiayaan syariah, aspek yuridis dalam prinsip kehatihatian, dan tinjauan mashlahah terhadap urgensi manajemen risiko berbasis syariah. Penelitian ini adalah penelitian hukum normatif menggunakan pendekatan perundang-undangan dan pendekatan maslahat dengan analisis deskriptif kualitatif. Hasil pembahasan menunjukkan bahwa sistem yang dinamis perlu pula didukung aspek yuridis agar memberikan kekuatan hukum dengan terwujudnya soliditas regulasi. Dalam tataran regulasi ini pula, selain aturan yang dikeluarkan OJK, fatwa DSN- 
MUI pula sangat diperlukan dan memiliki kedudukan yang begitu urgen. Sebab manajemen risiko pembiayaan juga adalah bagian dari muamalah yang harus tetap menjaga prinsip syariah, jangan sampai penerapan prinsip syariah hanya ada pada teknis produk, tetapi tidak diterapkan pada teknis pengelolaan risikonya. Kesyariahan yang diharapkan adalah pengaplikasian prinsip syariah yang total (kaffah), bukanlah yang bersifat parsial.

Kata kunci: Fatwa DSN-MUI, Manajemen Risiko, Pembiayaan Syariah

\section{Pendahuluan}

Bank syariah dalam menjalankan usahanya tidak terlepas dari sebuah risiko bisnis (business risk), termasuk persoalan kerugian yang dapat terjadi. Memperhatikan dan mempertimbangkan hal tersebut, maka bank syariah perlu menerapkan tata kelola risiko bisnis, mengingat bank syariah selain menghimpun dana dari masyarakat juga menyalurkannya dalam usaha pembiayaan yang berorientasi profit dan pasti terdapat risiko di dalamnya. Risiko yang perlu mendapat perhatian dalam manajemen perbankan syariah saat ini adalah pada aspek pembiayaan. Hasil penelitian menunjukkan bahwa pembiayaan Bank Syariah lebih tinggi risikonya (Non Performing Financing/NPF) dibandingkan dengan kredit bank konvensional (Non Performing Loan/NPL), ${ }^{1}$ kualitas NPL Bank Konvensional lebih baik dibandingkan NPF Bank Syariah ${ }^{2}$ dan masih perlu pembenahan dalam penanganan risiko pembiayaan Bank Syariah ini dalam upaya meningkatkan laba ${ }^{3}$. Proses pembiayaan yang kompleks melibatkan proses yang berawal dari pengumpulan informasi dan verifikasi nasabah serta objek pembiayaan, proses analisis dan persetujuan pembiayaan, proses administrasi dan pembukaan pembiayaan, proses pemantauan pembiayaan, hingga pelunasan dan penyelamatan pembiayaan. ${ }^{4}$

Dominasi sarana berbasis digital inovatif telah bergulir secara masif guna memenuhi kebutuhan manusia modern yang memiliki mobilitas tinggi sehingga menuntut efisiensi waktu, tenaga, sarana, dan biaya, dimana semuanya dapat dipastikan berhubungan erat dengan financial. Berbagai inovasi layanan digital berkembang secara dinamis dan bersaing satu sama lain secara terbuka untuk mendapatkan pangsa pasar di segala bidang industri. Terutama dengan masuknya era disrupsi, maka terjadilah fenomena mendisrupsi-terdisrupsi yang menyasar segala sektor termasuk keuangan. Dalam merespon era disrupsi ini, maka bank syariah dituntut untuk dapat bergerak dinamis menyesuaikan pada roda ekonomi yang berputar dengan masuk pada era disrupsi terutama pada revolusi industri yang telah sampai ada revolusi industri 4.0.

Komitmen OJK untuk menjalankan grand strategy pengembangan pasar keuangan perbankan syariah di antaranya berupaya untuk pencitraan baru perbankan syariah yang meliputi aspek positioning, differentiation, dan branding. Aspek diferensiasi dengan keunggulan kompetitif dengan produk dan skema yang beragam, transparans, kompeten dalam keuangan dan beretika, teknologi

1 Sitti Ruwaida Ramlan, Silcyljeova Moniharapon, dan Joy Elly Tulung, "Analisis Perbandingan Risiko Kredit Antara Bank Syariah Dan Bank Konvensional," Jurnal EMBA: Jurnal Riset Ekonomi, Manajemen, Bisnis dan Akuntansi 6, no. 1 (26 Februari 2018), https://doi.org/10.35794/emba.v6i1.19019.

2 Sasa Elida Sovia, Muhammad Saifi, dan Achmad Husaini, “Analisis Perbandingan Kinerja Keuangan Bank Konvensional Dan Bank Syariah Berdasarkan Rasio Keuangan Bank (Studi pada Bank Konvensional yang Terdaftar di BEI yang Memiliki Bank Syariah Periode 2012-2014)," Jurnal Administrasi Bisnis 37, no. 1 (2016): 134.

3 Sugiyarti Fatma Laela, "Kualitas Laba dan Corporate Governance: Benarkah Kualitas Laba Bank Syariah Lebih Rendah dari Bank Konvensional?," Jurnal Akuntansi dan Keuangan Indonesia 9, no. 1 (2014): 22-42.

4 Ikatan Bankir Indonesia, Mengelola Bisnis Pembiayaan Bank Syariah (Jakarta: Gramedia Pustaka Utama, 2015), 104. 
informasi yang selalu up-date dan user friendly, serta adanya ahli investasi keuangan syariah yang memadai. Program peningkatan kualitas layanan juga dilakukan dengan menciptakan SDM yang kompeten dan penyediaan teknologi informasi yang mampu memenuhi kebutuhan dan kepuasan nasabah serta mampu mengkomunikasikan produk dan jasa bank syariah kepada nasabah secara benar dan jelas, dengan tetap memenuhi prinsip syariah. prinsip syariah ini pula yang menjadi asas kegiatan usaha perbankan syariah, seharusnya tidak hanya terbatas pada teknis produk, tetapi juga aspek manajemen risiko, sebab manajemen risiko adalah bagian dari muamalah yang pengaplikasiannya tidak lepas dari aturan yang perlu dijaga dalam ruang lingkup hukum Islam.

DSN-MUI sebagai lembaga yang memegang otoritas fatwa ekonomi dan keuangan syariah di Indonesia dan termasuk didalamnya menyasar pada operasional Lembaga Keuangan Syariah (LKS) termasuk bank syariah telah banyak mengeluarkan fatwa yang mengatur akad dan produk keuangan syariah. Fatwa-fatwa tersebut pula telah diserap kepada Peraturan Otoritas Jasa Keuangan. Kedudukan Fatwa DSN-MUI sebagai pedoman ekonomi dan keuangan syariah sudah seharusnya mengatur secara menyeluruh terkait operasional yang ada di LKS, tidak hanya sebatat teknis produk, namun juga aspek pendukung dalam produk keuangan tersebut yakni segi manajemen risikonya. Pembiayaan yang disalurkan oleh lembaga keuangan syariah tidak lepas dari risiko Non Performing Financing (NPF) atau disebut juga pembiayaan bermasalah dengan terjadinya pembayaran angsuran yang macet oleh nasabah ataupun permasalahan lainnya yang berkaitan dengan kewajiban pembayaran. Oleh karena itu, artikel ini akan berupaya menelaah urgensi fatwa DSN-MUI mengenai manajemen risiko pembiayaan berbasis syariah dengan tiga bahasan yaitu karakteristik pembiayaan syariah, aspek yuridis prinsip kehati-hatian sebagai pijakan pentingnya manajemen risiko berbasis syariah, dan urgensi manajemen risiko berbasis syariah dalam pembiayaan syariah.

Metode penelitian yang diterapkan adalah penelitian hukum normatif dengan menggunakan pendekatan perundang-undangan (statute approach) dan pendekatan maslahat (maslahat approach). Data yang digali dalam penelitian ini adalah data sekunder yang didapatkan melalui studi literatur yang kemudian dianalisis secara deskriptif kualitatif. Hasil penelitian ini setidaknya dapat menjadi pertimbangan bagi DSN-MUI untuk menerbitkan fatwa manajemen risiko berbasis syariah agar dapat dipedomani LKS demi kesempurnaan pelaksanaan prinsip-prinsip syariah.

\section{Karakteristik Pembiayaan Syariah}

Pembiayaan di bank syariah memiliki karakteristik yang berbeda dibandingkan kredit di bank konvensional. Kredit perbankan konvensional berbentuk hutang-piutang atau pinjaman uang yang keuntungan ditarik dalam bentuk bunga pinjaman yang dalam syariat Islam adalah unsur terlarang untuk ada dalam muamalah karena tergolong riba, sedangkan pembiayaan perbankan syariah menggunakan akad-akad syariah yang bentuknya lebih bervariasi tetap menjaga transaksi dalam koridor syar'i. Akad dalam pembiayaan syariah seperti disebutkan sebelumnya tentang akad tijârah, terdapat pembiayaan dengan jenis natural certainty contracts (NCC) dengan karakter pertukaran dan natural uncertainty contracts (NUC) dengan karakter percampuran. 


\section{Gambar 1}

\section{NCC \& NUC dalam Pembiayaan Syariah}

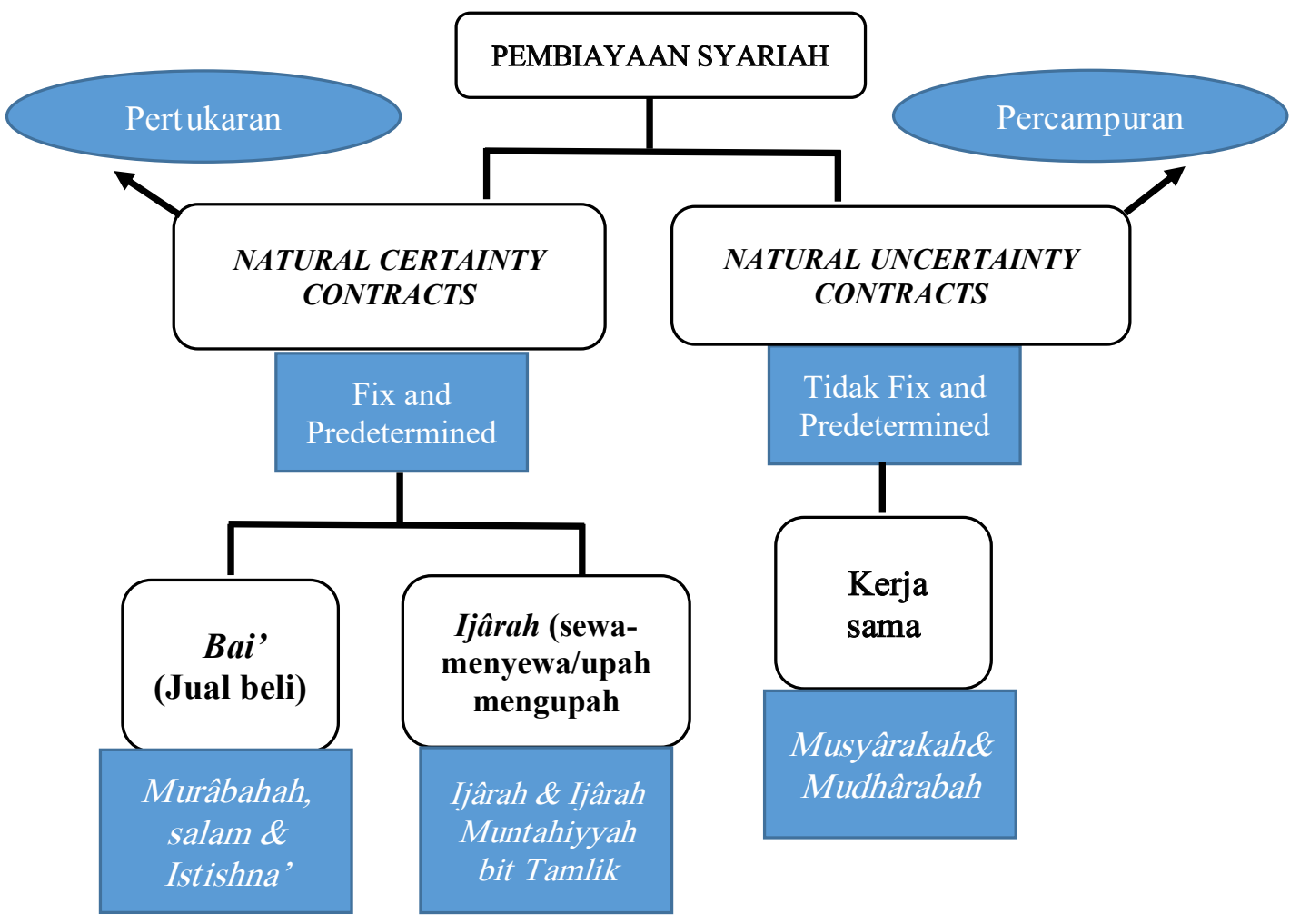

Pembiayaan syariah dari segi prinsip operasional, maka dapat diklasifikasikan sebagai berikut:

1. Prinsip bagi hasil

2. Prinsip jual beli

3. Prinsip sewa-menyewa

4. Prinsip pinjam-meminjam

Dikenal beberapa bentuk akad kerjasama dengan prinsip bagi hasil dalam fiqih muamalah, yakni musyârakah (syirkah), mudhârabah (qirâdh), muzâra'ah (ada yang membagi lagi dengan mukhâbarah), dan musâqah. Di antara akad-akad tersebut yang masyhur diaplikasikan dalam pembiayaan bank syariah adalah musyârakah dan mudhârabah.

Musyârakah adalah akad kerjasama antara dua pihak pemilik modal atau lebih yang bermitra usaha (kontribusi dana dan kerja) dengan kesepakatan menerima pembagian hasil dari usaha tertentu yang dijalani baik keuntungan maupun risiko kerugian yang mungkin saja terjadi. ${ }^{5}$ Pembiayaan musyârakah di perbankan syariah terjadi antara bank syariah dengan nasabah pembiayaan yang mereka bersepakat mencampurkan modal berkongsi untuk sebuah proyek atau usaha dengan ditentukannya nisbah bagi hasil dalam keuntungan yang dibagi nanti. Jadi bank dan nasabah dalam akad ini berposisi sebagai pemilik modal yang saling berserikat satu sama lain.

Mudhârabah adalah akad kerja sama antara pemilik dana (shâhibul mâl) dan pengelola dana (mudhârib) dalam usaha produktif dengan ketentuan nisbah bagi hasil dari kesepakatan kedua belah

5 Muhammad Syarif Hidayatullah, Perbankan Syariah: Pengenalan Fundamental dan Pengembangan Kontemporer (Banjarbaru: Dreamedia, 2017), 83. 
pihak. Pemilik dana memberikan suntikan dana $100 \%$ kepada pengelola dana untuk menjalani bisnisnya. ${ }^{6}$ Mudhârabah disebut pula dengan terminologi qirâdh dalam literatur fiqih, dalam transaksi ini pengelola modal tidak wajib menanggung kerugian, kecuali karena kecerobohan dan kelengahan (kelalaian). Apabila ada keuntungan dan kerugian, maka kerugian itu harus ditutup dengan keuntungan. ${ }^{7}$ Pembiayaan mudhârabah di perbankan syariah, maka bank syariah sebagai shâhibul mâl dan nasabah pembiayaan sebagai mudhârib. Jadi bank syariah menyaalurkan pembiayaan yang akan digunakan nasabah untuk bisnis yang ia jalankan dengan ketentuan nisbah bagi hasil yang disepakati ketika akad.

Salah satu pembeda antara bank syariah dan bank konvensional adalah pada sistem yang dijalankan. Bank syariah melakukan operasi berdasarkan prinsip syariah dan salah satunya adalah melalui pendapatan yang didapatkan dengan sistem bagi hasil, berbedahalnya dengan bank konvensional yang pendapatannya berasal dari sistem bunga.

Tabel 1

Perbedaan Bunga dan Bagi Hasil

\begin{tabular}{|l|l|}
\hline Bunga & Bagi Hasil \\
\hline $\begin{array}{l}\text { Penentuan bunga dibuat pada waktu aqad } \\
\text { dengan asumsi harus selalu untung. }\end{array}$ & $\begin{array}{l}\text { Penentuan besarnya rasio/nisbah bagi hasil } \\
\text { dibuat pada waktu akad dengan berpedoman } \\
\text { pada kemungkinan untung atau rugi. }\end{array}$ \\
\hline $\begin{array}{l}\text { Penentuan besarnya hasil diawal sebelum } \\
\text { proyek usaha dijalankan }\end{array}$ & $\begin{array}{l}\text { Penentuan besarnya hasil diketahui setelah } \\
\text { proyek usaha dijalankan }\end{array}$ \\
\hline Dihitung dari pokok pinjaman & $\begin{array}{l}\text { Dihitung dari nisbah bagi hasil yang diambil } \\
\text { dari keuntungan riil. }\end{array}$ \\
\hline $\begin{array}{l}\text { Persentase dapat berubah sesuai kondisi } \\
\text { (bunga) pasar. }\end{array}$ & Nisbah tetap sesuai akad \\
\hline $\begin{array}{l}\text { Nominal tetap sesuai bunga: Jumlah } \\
\text { pembayaran bunga tidak meningkat sekalipun } \\
\text { jumlah keuntungan berlipat atau keadaan } \\
\text { ekonomi sedang booming) }\end{array}$ & $\begin{array}{l}\text { Nominal berubah sesuai kondisi usaha: Jumlah } \\
\text { peningkatan jumlah pendapatan) }\end{array}$ \\
\hline Eksistensi bunga diragukan & Tidak adayang meragukan keabsahan bagi hasil \\
\hline
\end{tabular}

Selain akad berprinsip bagi hasil, maka pembiayaan bank syariah dapat pula menerapkan pembiayaan berprinsip jual beli (bai'). Legalitas jual beli terdapat dalam Q.S. al-Baqarah [2] ayat 275: "Allah menghalalkan jual beli dan mengharamkan riba". Terdapat berbagai macam bentuk transaksi jual beli yang dikenal dalam fiqih Islam. Pembagian jual beli tersebut didasarkan pada perspektif yang digunakan dalam hal membaginya.

\footnotetext{
Hidayatullah, 79.

7 Musthafa Dib al-Bugha, Kompilasi Hukum Islam ala Madzhab Syafi'i (Surabaya: al-Hidayah, 2009), 360.
} 
Tabel 2

Klasifikasi Jual Beli dalam Fiqih Islam

\begin{tabular}{|c|c|c|c|c|c|}
\hline No & Perpektif & Jual Beli & \multicolumn{3}{|l|}{ Keterangan } \\
\hline \multirow{3}{*}{1} & \multirow{3}{*}{$\begin{array}{l}\text { Objek yang } \\
\text { diperjual belikan }\end{array}$} & Bai' al mutlaqah & \multicolumn{3}{|c|}{ Pertukaran uang dengan barang } \\
\hline & & Bai' ash sharf & \multicolumn{3}{|c|}{ Pertukaran uang dengan uang } \\
\hline & & $\begin{array}{l}\text { Bai'al } \\
\text { muqayyadah }\end{array}$ & \multicolumn{3}{|c|}{ Pertukaran barang dengan barang (barter) } \\
\hline \multirow{6}{*}{2} & \multirow{6}{*}{$\begin{array}{l}\text { Cara menetapkan } \\
\text { harga (Standarisasi } \\
\text { harga) }\end{array}$} & $\begin{array}{l}\text { Bai'al } \\
\text { musâwamah }\end{array}$ & \multicolumn{3}{|c|}{$\begin{array}{l}\text { Jual beli biasa dimana penjual tidak menyebutkan harga pokok } \\
\text { (modal) dan keuntungannya, melainkan langsung menyebutkan } \\
\text { harga jual }\end{array}$} \\
\hline & & \multirow{3}{*}{ Bai' al amanah } & \multirow{3}{*}{$\begin{array}{ll}\text { Jual beli dimana penjual } \\
\text { meyebutkan } & \text { harga } \\
\text { pokok (modal) }\end{array}$} & Murâbahah & $\begin{array}{l}\text { Jual beli dengan } \\
\text { menyebutkan harga } \\
\text { pokok (modal) dan } \\
\text { keuntungan yang } \\
\text { dinginkan }\end{array}$ \\
\hline & & & & $\begin{array}{l}\text { Muwâdha'ah atau } \\
\text { wadhi'ah }\end{array}$ & $\begin{array}{l}\text { Jual beli dibawah } \\
\text { harga modal dengan } \\
\text { jumlah kerugian } \\
\text { yang diketahui } \\
\end{array}$ \\
\hline & & & & 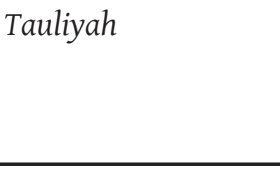 & $\begin{array}{l}\text { Jual beli dengan } \\
\text { harga modal (tanpa } \\
\text { keuntungan dan } \\
\text { kerugian) }\end{array}$ \\
\hline & & Bai' al muzâyadah & \multicolumn{3}{|c|}{$\begin{array}{l}\text { Jual beli dengan penawaran dari penjual dan para pembeli berlomba } \\
\text { menawar, lalu penawar tertinggi terpilih sebagai pembeli. Disebut } \\
\text { juga jual beli lelang. }\end{array}$} \\
\hline & & $\begin{array}{l}\text { Bai'al } \\
\text { munâqadhah }\end{array}$ & \multicolumn{3}{|c|}{$\begin{array}{l}\text { Kebalikannya dari Bai' al muzâyadah, yaitu jual beli dengan } \\
\text { penawaran pembeli untuk membeli barang dengan spesifikasi } \\
\text { tertentu dan para penjual berlomba menawarkan dagangannya, } \\
\text { kemudian pembeli akan membeli dari penjual yang menawarkan } \\
\text { harga termurah }\end{array}$} \\
\hline \multirow{6}{*}{3} & \multirow{6}{*}{$\begin{array}{l}\text { Cara pembayaran } \\
\text { atau transaksi yang } \\
\text { dilakukan }\end{array}$} & $\begin{array}{l}\text { Jual beli tunai } \\
\text { (bai' naqdan) }\end{array}$ & $\begin{array}{l}\text { Jual beli dengan pe } \\
\text { langsung }\end{array}$ & mbayaran dan peny & erahan barang secara \\
\hline & & \multirow{5}{*}{$\begin{array}{l}\text { Jual beli tidak } \\
\text { tunai/tangguh/ } \\
\text { tunda }\end{array}$} & \multirow{2}{*}{ 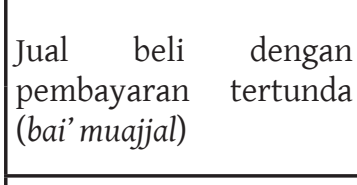 } & \multicolumn{2}{|c|}{$\begin{array}{l}\text { Pembayaran penuh pada waktu yang } \\
\text { telah ditentukan dikemudian hari }\end{array}$} \\
\hline & & & & \multicolumn{2}{|c|}{$\begin{array}{l}\text { Pembayaran dengan angsuran/cicilan } \\
\text { (bai' taqsith) }\end{array}$} \\
\hline & & & \multirow{2}{*}{$\mid \begin{array}{ll}\text { Jual beli } & \text { dengan } \\
\text { penyerahan } & \text { barang } \\
\text { tertunda } & \end{array}$} & \multicolumn{2}{|c|}{$\begin{array}{l}\text { Bai' as salam yaitu jual beli ketika } \\
\text { pembeli membayar tunai di muka atas } \\
\text { barang yang dipesan (biasanya produk } \\
\text { pertanian) dengan spesifikasinya yang } \\
\text { akan diserahkan kemudian }\end{array}$} \\
\hline & & & & \multicolumn{2}{|c|}{$\begin{array}{l}\text { Bai' al Istishna' yaitu jual beli dimana } \\
\text { pembeli membayar tunai atau } \\
\text { bertahap atas barang yang dipesan } \\
\text { (biasanya produk manufaktur) dengan } \\
\text { spesifikasinya yang harus diproduksi dan } \\
\text { diserahkan kemudian }\end{array}$} \\
\hline & & & \multicolumn{3}{|c|}{$\begin{array}{l}\text { Jual beli dengan pembayaran dan penyerahan barang sama-sama } \\
\text { tertunda atau jual beli utang dengan utang (bai' al kâli bil kâli atau } \\
\text { bai' dayn bid dayn) }\end{array}$} \\
\hline
\end{tabular}

8 Ulama sepakat (konsensus) bahwa transaksi al kâli bil kâli adalah transaksi terlarang. 
Pembiayaan murâbahah adalah pembiayaan yang begitu populer di bank syariah. pembiayaan ini menarik keuntungan dalam bentuk margin. Keuntungan dalam akad jual beli murâbahah bersifat fix dan ditetapkan diawal akad antara nasabah dan bank syariah. Dalam operasionalnya, pembiayaan murâbahah merupakan transaksi yang transparan dengan penyebutan harga perolehan (harga pokok barang) dan margin yang ditambahkan sehingga didapatkanlah harga jual untuk selanjutnya dilakukan kesepakatan. Murâbahah yang dipraktikkan di bank syariah berbeda dengan murâbahah murni yang dipraktikkan di masyarakat umum. Murâbahah modern yang telah menjadi produk keuangan lembaga keuangan syariah dapat dikategorikan jenis murâbahah lil 'amir bisy syira atau murâbahah kepada pemesan pembelian. Dikarenakan bank syariah adalah lembaga intermediasi yang tidak menyediakan stok barang atau aset yang diperjual belikan. Maka bank syariah melakukan pembelian adalah ketika didahului pemesanan (pengajuan pembiayaan pengadaan barang oleh nasabah). transaksi seperti itulah yang disebut dengan murâbahah lil 'amir bisy syirâ', karena bank syariah bertindak sesudah adanya pemesanan pembelian oleh nasabah. Objek pembiayaan murâbahah di bank syariah bisa bersifat penyediaan jenis barang untuk digunakan sendiri atau disebut murâbahah konsumtif seperti rumah, kendaraan bermotor dan barang konsumsi lainnya, dan bentuk lainnya bisa bersifat penyediaan barang untuk usaha atau disebut murâbahah produktif seperti alat-alat produksi usaha atau penunjang usaha dan barang-barang investasi lainnya.

Akad lainnya yang dapat diterapkan dalam pembiayaan syariah adalah akad ijârah. Secara bahasa Ijârah berasal dari kata al-ajru artinya ganti, upah, atau menjual manfaat. ${ }^{9}$ Sedangkan menurut syara' ijârah ialah memberikan kemanfaatan sesuatu dengan ada penukaran. Secara teknisnya maka ijârah adalah sebuah akad pemberian manfaat (hak guna) baik dari barang maupun tenaga kerja (jasa) dengan adanya imbalan sebagai ganti pengambilan manfaat tersebut. Jadi ijârah ketika berhubungan dengan barang dapat diistilahkan sewa-menyewa, sedangkan ketika berhubungan dengan jasa diistilahkan upah-mengupah atau perburuhan. ${ }^{10}$

Istilah ijârah di Bank Syariah mengalami perkembangan dengan adanya istilah ijârah muntahiyah bit tamlik atau dapat pula disebut ijârah wa iqtina ataupun bai'ut tajkiri. Jika dalam ijarah berbentuk sewa murni, yakni sebatas mengambil manfaatnya saja tanpa pemindahan kepemilikan, maka dalam ijârah muntahiyyah bit tamlik berbentuk seperti sewa beli, yakni sewa yang berujung pada pemindahan kepemilikan dari yang menyewakan (Bank) kepada penyewa (nasabah) baik secara jual beli maupun hibah. Di Malaysia, produk seperti ijârah muntahiyyah bit tamlik dikenal dengan istilah al-ijârah thumma al-bai'. Pemindahan kepemilikan dalam ijarah muntahiyyah bit tamlik baik secara jual beli maupun hibah dilaksanakan setelah akad ijârah selesai. Jadi dilaksanakan terlebih dahulu ijârah murni dalam periode tertentu, kemudian disaat akad tersebut telah selesai, barulah antara nasabah dan pihak bank melakukan akad pemindahan kepemilikan. Jadi antara akad jual beli dan sewa tidak dikumpulkan atau tercampur dalam satu transaksi.

Telah disebutkan sebelumnya tiga jenis pembiayaan syariah komersial yaitu pembiayaan berprinsip bagi hasil dengan pendapatan yang didapatkan berdasarkan nisbah bagi hasil, kemudian pembiayaan berprinsip jual beli yang pendapatan berupa margin yang ditambahkan dari harga perolehan (modal), selanjutnya ada pembiayaan berprinsip sewa-menyewa yang pendapatannya adalah berbentuk fee/ujrah. Jenis keempat berbeda dengan tiga jenis pembiayaan sebelumnya,

9 Ismail Nawawi, Fikih Muamalah Klasik dan Kontemporer (Bogor: Ghalia Indonesia, 2012), 185.

10 Hidayatullah, Perbankan Syariah: Pengenalan Fundamental dan Pengembangan Kontemporer, 99-100. 
karena tiga prinsip pembiayaan sebelumnya bersifat komersial, sedangkan yang keempat bersifat sosial yang tidak boleh ditarik keuntungannya di dalamnya yaitu pembiayaan berprinsip pinjammeminjam. Prinsip pinjam-meminjam ini terwujud dalam akad qardh atau pinjaman uang murni yang tidak boleh ditambahkan keuntungan di dalamnya yang akan berakibat menjadi transaksi terlarang dengan adanya bunga pinjaman yang terkategorikan riba yang diharamkan dalam Islam.

Di bank syariah, terdapat isitilah qardhul hasan. Qardhul hasan merupakan produk turunan dari qardh dan merupakan akad pemberian pinjaman uang guna kepentingan sosial atau membantu orang-orang yang membutuhkan. Qardhul hasan dalam Kamus Perbankan Syariah diartikan pinjaman sosial/kebajikan sebagai produk untuk membantu usaha kecil (golongan ekonomi lemah) atau membantu sektor sosial tanpa imbalan, dan pengembaliannya dapat dilakukan secara sekaligus atau cicilan dalam waktu tertentu. ${ }^{11}$ Penjelasan lain menurut Wirdyaningsih dkk, pembiayaan qardhul hasan yaitu pembiayaan berupa pinjaman tanpa dibebani biaya apapun bagi kaum dhuafa yang merupakan asnaf zakat/infak/sedekah dan ingin mulai berusaha kecil-kecilan. ${ }^{12}$

\section{Aspek Yuridis Prinsip Kehati-hatian sebagai Pijakan dalam Pengaplikasian Manajemen Risiko Pembiayaan}

Secara umum dalam dunia perbankan terdapat beberapa prinsip yang menjadi landasan operasional perbankan dalam menjalankan aktivitas ekonominya. Prinsip-prinsip yang dimaksud adalah sebagai berikut:

1. Prinsip kepercayaan (fiduciary relation principle), yakni prinsip yang mendasari aktivitas bank untuk menghimpun dana masyarakat. Bank pada saat menjalankan operasionalnya untuk menghimpun dana masyarakat harus mampu menimbulkan kepercayaan (trust) kepada para nasabah bahwa dana yang dihimpun akan dikelola berdasarkan prinsip pengelolaan perusahaan yang sehat atau good corporate governance. ${ }^{13}$ Landasan hukumnya terdapat dalam Pasal 29 Ayat (4) UU No. 10 Tahun 1998 Tentang Perubahan UU No. 7 Tahun 1992 Tentang Perbankan dan Pasal 51 Ayat (1) UU No. 21 Tahun 2008 tentang Perbankan Syariah.

2. Prinsip kehati-hatian (prudential principle), yakni prinsip yang mengharuskan bank pada saat menyalurkan dana ke nasabah harus berhati-hati dalam kerangka business judgement rules atau pertimbangan bisnis terhadap keputusan terbaik yang diambil oleh bank. ${ }^{14}$ Landasan hukumnya yakni Pasal 2 UU No. 10 UU Perbankan dan Pasal 2 UU Perbankan Syariah.

3. Prinsip kerahasiaan (secrecy principle), yakni prinsip yang mendasari bahwa bank dalam menjalankan aktivitas ekonominya wajib merahasiakan keterangan mengenai nasabah penyimpanan dan simpanannya. Namun demikian, kewajiban merahasiakan data nasabah tidak berlaku mutlak, melainkan dapat dikecualikan atau dibuka atau dengan alasan-alasan yang diakui secara hukum. ${ }^{15}$ Landasan hukumnya yakni Pasal 41 - 43 UU Perbankan Syariah.

4. Prinsip mengenal nasabah (know your customer principle), yakni prinsip yang mengharuskan pihak bank untuk mengenal dan mengetahui identitas nasabah terutama bonafiditas pribadi

\footnotetext{
${ }_{11}$ Isriani Hardiani dan Muh. H. Giharto, Kamus Perbankan Syariah (Bandung: Marja, 2007), 60.

12 Wirdyaningsih dkk., Bank dan Asuransi Islam di Indonesia (Jakarta: Kencana Prenada Media, 2005), 127.

13 Noor Hafidah, Hukum Jaminan Syariah \& implementasinya dalam perbankan syariah di indonesia (Yogyakarta: UII Press, 2017$), 2$.

14 Hafidah, 2.

15 Hafidah, 3.
} 
nasabah dan/atau bidang usahanya, termasuk mencermati setiap transaksi yang mencurigakan yang dilakukan oleh nasabah. Landasan hukumnya terdapat dalam Peraturan Bank Indonesia No. 3/10/PBI/2001 tentang Penerapan Prinsip Mengenal Nasabah. Tujuan utama penerapan prinsip tersebut selain untuk melindungi bank dari berbagai aktivitas bisnis yang bertentangan dengan hukum dan merugikan bank, juga untuk melindungi nama baik dan reputasi lembaga keuangan.

Mengingat adanya prinsip "No Risk No Return" maupun "Hight Risk Hight Return" dalam dunia bisnis yang memang diakui dalam ilmu ekonomi, maka hal tersebut juga berlaku pada bank syariah. Dari keempat prinsip yang telah disebutkan di atas, maka menjadi suatu yang begitu signifikan dalam pengendalian risiko pembiayaan yang disebut prinsip kehati-hatian dalam perbankan (purdential banking principle). Prinsip ini menjadi landasan yang urgen untuk diperhatikan dan mampu diterapkan agar operasional dapat berjalan dengan ideal dan stabil. Amanat diperintahkannya prinsip kehati-hatian pada perbankan di Indonesia terdapat dalam undang-undang perbankan seperti UU No.10 Tahun 1998 tentang Perubahan atas UU No. 7 Tahun 1992 tentang Perbankan dan UU No 21 Tahun 2008 tentang Perbankan Syariah.

Menurut Veithzal Rivai dan Andria Permata Veithzal bahwa prinsip kehati-hatian merupakan prinsip untuk melindungi pembiayaan dari berbagai permasalahan dengan cara mengenal customer baik melalui identitas calon customer maupun dokumen pendukung informasi dari calon customer. ${ }^{16}$ Kemudian Permadi Gandapradja mengartikan prinsip kehati-hatian adalah konsep yang memiliki unsur sikap, prinsip, standar kebijakan dan teknik manajemen risiko bank yang sedemikian rupa, sehingga dapat menghindari akibat sekecil apapun yang dapat membahayakan atau merugikan stakeholder, terutama para nasabah deposan dan bank sendiri. ${ }^{17}$ Melihat pada definisi yang diuraikan sebelumnya, maka prinsip kehati-hatian adalah landasan manajemen risiko yang bertujuan untuk menjaga dana masyarakat atau nasabah deposan agar tetap aman dan tidak mengalami kerugian untuk terciptanya stabilitas keuangan bagi bank.

Bank syariah sebagai lembaga intermediasi atau lembaga yang menghimpun dana dari masyarakat, memperhatikan hal itu maka bank syariah perlu untuk mengelola kegiatan usahanya berdasarkan prinsip kehati-hatian dengan penerapan yang optimal. Berbeda dengan bank konvensional dalam penyaluran dananya menggunakan istilah kredit, di bank syariah penyaluran dana cendrung menggunakan istilah pembiayaan.

Pembiayaan adakalanya dengan mengambil keuntungan berdasarkan margin seperti dalam akad jual beli murâbahah, salam, istishna'; ujrah (upah/biaya sewa) dalam akad ijarah; dan bagi hasil dalam pembiayaan melalui akad musyârakah dan mudharabah. Kedua akad pembiayaan berdasar bagi hasil ini dilihat dari ciri khasnya sangat berbeda sekali dengan akad yang lain. Di antara perbedaan menonjol adalah bahwa bank syariah dalam penyaluran dananya kepada nasabah penerima pembiayaan tidak dapat dipastikan memperoleh keuntungan tertentu (modal pembiayaan ditambah return) sebagaimana dalam skim pembiayaan yang mengambil keuntungan berdasarkan margin keuntungan. Akan tetapi, justru pihak bank sangat memungkinkan mengalami kerugian bila usaha nasabahnya mengalami kegagalan atau kebangkrutan. Inilah konsekuensi dari skim

\footnotetext{
${ }^{16}$ Veithzal Rivai dan Andria Permata Veithzal, Islamic Financial Manaement: Teori, Konsep dan Aplikasi Panduan Praktis untuk Lembaga Keuangan, Nasabah, Praktisi, dan Mahasiswa (Jakarta: RajaGrafindo Persada, 2008), 149-50.

17 Permadi Gandapradja, Dasar dan Prinsip Pengawasan Bank (Jakarta: Gramedia Pustaka Utama, 2004), 21.
} 
pembiayaan dengan prinsip bagi hasil (profit and loss sharing). Namun, sebaliknya bila usaha nasabah berhasil maka akan memperoleh bagi hasil yang mungkin lebih besar bila dibandingkan penyaluran dana melalui skim pembiayaan berdasarkan margin keuntungan, ini karena di antara kedua pihak (bank dan nasabah) telah ada kesepakatan nisbah bagi hasilnya berbentuk persentase seperti 50:50, 60:40, 70:30 dan lain-lain.

Prinsip syariah dalam sistem perbankan syariah selain melarang transaksi riba, juga melarang transaksi yang didasarkan pada motif spekulasi, artinya harus selalu berkaitan dengan kegiatan riil. Sistem ekonomi syariah secara ideal adalah berbasis equitas, oleh karena itu aktiva produktif bank syariah seharusnya lebih didominasi oleh pembiayaan yang bersifat equity financing yaitu musyârakahdan mudhârabahyang lebih dikenal sebagai pembiayaan dengan prinsip bagi hasil (profit and loss sharing). Pembiayaan dengan prinsip bagi hasil ini memiliki keterkaitan langsung dengan sektor riil karena pembiayaan bank langsung ditujukan pada kegiatan ekonomi riil yang diharapkan memberikan nilai tambah yang dapat dibagi hasilkan. Pembiayaan yang berdasarkan debt financing atas dasar jual beli seperti murâbahah, salam, dan istishna' serta ijârah muntahiyyah bit tamlik pada dasarnya juga terkait langsung dengan sektor riil. Namun dampak nilai tambah ekonomi yang ditimbulkan lebih kecil dibandingkan dengan pembiayaan bagi hasil

Atas dasar manajemen risiko dalam skema pembiayaan, maka umumnya bank syariah sangat berhati-hati dalam melakukan penyaluran dana melalui skim ini. Apalagi kalau mengingat bahwa bank syariah sebagaimana bank konvensional juga merupakan lembaga intermediasi keuangan. Dana yang dikelola oleh bank sebagian besar merupakan dana pihak ketiga (nasabah deposan/ penabung) baik yang berupa produk tabungan, giro, maupun depostio dan baik akad wadi'ah maupun mudhârabah. Sebagaimana lazimnya juga, bahwa dana nasabah tersebut sewaktu-waktu atau dalam jangka waktu tertentu akan diambil kembali oleh nasabah deposan.

\section{Urgensi Fatwa DSN-MUI Mengenai Manajemen Risiko Pembiayaan Berbasis Syariah}

Memandang eksistensi ekosistem keuangan perbankan syariah, maka seharusnya ada perbedaan daripada pengaturan perbankan konvensional termasuk dalam persoalan manajemen risiko pembiayaan termasuk yang berbasis digital kaitannya dengan era disrupsi revolusi industri 4.0. Karena itu tidak cukup, teknis produk dan manajemen risiko di atur oleh BI maupun OJK, namun ada peran Dewan Syariah Nasional (DSN) sebagai bagian dari Majelis Ulama Indonesia (MUI) melalui perangkat fatwanya sebagai fatwa yang keberadaanya dilegitimasi oleh undang-undang sebagaimana terdapat dalam pengaturan Undang-undang No. 21 Tahun 2008 tentang Perbankan Syariah sebagai landasan dan pegangan prinsip syariah. ${ }^{18}$ Bank syariah tidak hanya memperhatikan aspek teknis pada kemudahan dan profit, tetapi juga yang sangat penting adalah menjaga agar kebijakan transaksi yang dilakukan tidak bertentangan dengan prinsip syariah atau tetap selaras dengan niliai-nilai syariah dalam bermuamalah.

Untuk produk keuangan terkait digitalisasi, maka DSN-MUI telah mengeluarkan Fatwa DSN NO: 116/DSN-MUI/IX/2017 tentang uang elektronik syariah dan Fatwa DSN No: 117/DSN-MUI/ II/2018 tentang Layanan Pembiayaan Berbasis Teknologi Informasi Berdasarkan Prinsip Syariah. Namun lebih dari itu, ini masih sebatas pengaturan teknis produk keuangan. Sedangkan pengaturan

\footnotetext{
$\overline{18}$ Nunung Rodliyah, Nila Nargis, dan Abdur Rohman Husen, "Kedudukan Fatwa Terhadap Dasar Hukum Penyelesaian Sengketa
} Ekonomi Syariah Melalui BASYARNAS," Nizham Journal of Islamic Studies 7, no. 01 (12 Juli 2019): 10. 
tentang manajemen risiko pembiayaan secara umum seperti pengadaan jaminan dalam aspek screening pembiayaan dan penanganan non performing financing/pembiayaan bermasalah (penagihan piutang, reconditioning, rescheduling, restructuring dan pengeksekusian jaminan) maupun manajemen risiko pembiayaan berbasis digital secara khusus masih belum ada dan sebenarnya penting untuk dibuat. Karena kesyariahan produk, tidak hanya pada teknis prosedur produk, tetapi penting untuk menerapkan manajemen risiko produk yang juga sesuai prinsip syariah terutama pada saat ini terhadap manajemen risiko yang terkait digitalisasi perbankan syariah khususnya dan ekonomi keuangan syariah umumnya. DSN-MUI perlu merumuskan Fatwa terkait pedoman manajemen risiko pembiayaan berbasis syariah. Sebab, eksistensi Fatwa DSN-MUI menjadi benteng dalam menjaga ekosistem keuangan syariah yang komprehensif. Memang sudah seharusnya religiusitas dalam sektor ekonomi melalui transaksi keuangan syariah yang dilakukan itu bersifat total. ${ }^{19}$ Jika kesyariahan hanya dipraktikkan pada teknis prosedural akad produk, namun tidak mempedulikan pada teknis penerapan manajemen risikonya yang ternyata bisa saja terjadi penyimpangan yang hakikatnya bertentangan dengan prinsip syariah, maka perwujudan "syariah" hanya terlaksana secara parsial saja, sesuatu yang awalnya syariah, namun saat terjadi permasalahan maka ditangani dengan cara yang keliru dan melenceng dari nilai syariah. ${ }^{20}$

Bank syariah sebagai lembaga keuangan yang berorientasi komersial atau bergerak pada sektor bisnis dalam operasionalnya sudah tentu terdapat risiko, sebab dalam berbisnis terdapat konsekuensi untung dan rugi. Manajemen menjadi bagian penting dalam menjalankan bisnis, sebab tujuan diterapkannya manajemen adalah untuk dapat mencapai tujuan perusahaan, menciptakan keteraturan dan keseimbangan dan dapat menjalankan operasional secara efektif dan efisien. ${ }^{21}$ Dengan begitu akan terwujud produktivitas karena produktivitas sendiri adalah kombinasi dari efektivitas dan efisiensi. ${ }^{22}$ Penerapan manajemenpun perlu beradabtasi dengan perubahan dan perkembangan zaman karena ini dapat memengaruhi keberhasilan, ${ }^{23}$ namun bagaimanapun aktivitas manajemen beradabtasi dengan perubahan yang terjadi, pada sektor ekonomi dan keuangan syariah khususnya tetap saja tidak boleh penerapan manajemen ini dilakukan dengan bebas nilai dan tanpa aturan yang menjadi batasannya terutama ketentuan syariah, Berdasarkan hal tersebut, maka bank syariah dalam operasionalnya perlu mengaplikasikan manajemen risiko bisnis. Hal ini menjadi penting, dikarenakan pula bank syariah selain menghimpun dana dari masyarakat melalui produk simpanan juga menyalurkannya dalam produk pembiayaan yang sifatnya komersial (berorientasi profit) dan sudah pasti ada risiko yang menyertainya.

Kaidah fikih yang menjadi prinsip dasar muamalah adalah sebagai berikut:

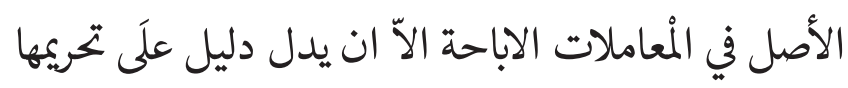

"Pada dasarnya semua muamalah boleh dilakukan, terkecuali ada dalil yang mengharamkannya." 24

\footnotetext{
${ }^{19}$ Muhammad Syarif Hidayatullah, "Islamic Economics And Partial-Total Religiosity: A Case Study Of Majlis Taklim In Banjarmasin,” Islamuna: Jurnal Studi Islam 7, no. 1 (12 Juni 2020): 51-52, https://doi.org/10.19105/islamuna.v7i1.3308.

${ }^{20}$ Hidayatullah, 51-52.

21 T. Hani Handoko, Manajemen (Yogyakarta: BPFE-Yogyakarta, 2003), 6-7.

22 Parastoo Roghanian, Amran Rasli, dan Hamed Gheysari, "Productivity through effectiveness and efficiency in the banking industry," Procedia-Social and Behavioral Sciences 40 (2012): 551.

${ }^{23}$ Revenio Jalagat, "The impact of change and change management in achieving corporate goals and objectives: Organizational perspective," International Journal of Science and Research 5, no. 11 (2016): 1233.

24 Fathurrahman Azhari, Qawaid Fiqhiyyah Muamalah (Banjarmasin: Lembaga Pengembangan Kualitas Umat, 2014), 156.
} 
Berdasarkan pada kaidah fikih di atas, maka kreasi dan inovasi produk keuangan yang merupakan bagian dari mumalah boleh dilakukan, selama tidak terkandung unsur-unsur terlarang di dalamnya, termasuk pada upaya mengelola risiko bisnis. Sebab bisnis adalah pengambilan risiko, karena risiko selalu terdapat dalam aktivitas komersial.

Risiko pula menjadi pembahasan dalam ekonomi syariah. Dalam ilmu ekonomi konvensional, dikenal prinsip atau slogan "no risk no return" atau "hight risk hight return", maka dalam kaidah fikih

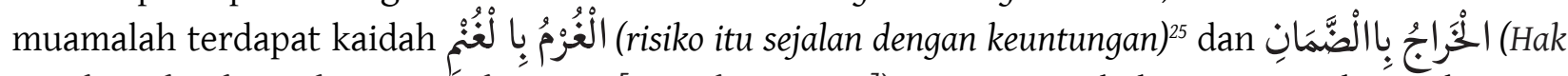
mendapat hasil itu sebagai ganti kerugian [yang ditanggung]). ${ }^{26}$ Mengingat bahwasanya pula pembiayaan bank syariah dan kredit bank konvensional, akad yang menjadi dasar operasional jelas berbeda yang berakibat pada perbedaan karakteristik dan konsekuensi hukum.

Bank syariah dalam pembiayaannya tidak menerapkan pinjaman berbasis bunga sebagaimana bank konvensional, melainkan menerapkan akad-akad syariah yang memang dibolehkan secara hukum syara' dalam pengambilan keuntungan atau digunakan dalam operasional produk komersial. Salah satunya pembiayaan berbasis profit and loss sharing (PLS) dengan akad mudharabah dan musyarakah yang dalam praktiknya merupakan pembiayaan dengan intensitas risiko tinggi karean pembiayaan dengan akad ini sangat memerlukan moralitas tinggi dari nasabah, karena itu dalam pengaplikasian akad ini dalam produk pembiayaan akan dihadapkan pada risiko moral hazard dan asymmetric information. Oleh sebab itu menurut widarjono, Anto dan Fakhrunnas, akad PLS ini dapat mengalami potensi gangguan lebih besar dibandingkan akad lainnya. ${ }^{27}$

Sistem manajemen risiko pada lembaga keuangan syariah harus mampu mengatasi karakteristik dan atribut unik yang terkait dengan pembiayaan syariah dengan operasional yang melibatkan kontrak dan instrumen keuangan yang dalam proses pengaplikasiannya dalam suatu sektor bisnis tidak lepas dari keberadaan risiko yang menyertainya. Infrastruktur manajemen risiko perlu tersedia untuk memfasilitasi tindakan identifikasi, pengukuran, pemantauan dan pengendalian atas semua risiko bawaan yang ada di semua jenis pembiayaan yang beragam. Oleh karena itu, kompleksitas masing-masing risiko dalam akad dan instrumen keuangan syariah perlu untuk sepenuhnya dieksplorasi dan diukur untuk memberikan penilaian dan manajemen yang efektif. ${ }^{28}$

Bank syariah sebagai bagian dari pasar keuangan syariah mendasarkan operasional usahanya kepada prinisp syariah. Mohammed Obaedullah menyebutkan norma-normat terkait dengan pasar keuangan syariah yakni kebebasan berkontrak, bebas dari riba, bebas dari gharar (excessive uncertainty), bebas dari qimar (gambling) dan maysir (uneraned income), bebas dari manipulasi harga, hak untuk bertransaksi dengan harga yang wajar, hak atas informasi yang sama, memadai dan akurat, bebas dari dharar (sesuatu yang membahayakan) dan mengakomodir kemaslahatan. ${ }^{29}$ Lalu Daud Vicary Abdullah dan Keon Chee merumuskan prinsip keuangan syariah dengan lima prinsip utama yaitu keyakinan pada tuntutan Ilahi, tidak ada bunga, tidak ada investasi haram, berbagi risiko dianjurkan dan pembiayaan didasarkan pada aset riil. ${ }^{30}$ Kemudian Muhammad Fauzan menyebutkan bahwa prinsip

25 Azhari, 258.

26 Azhari, 241.

27 Agus Widarjono, MB ANTO, dan Faaza Fakhrunnas, "Financing Risk in Indonesian Islamic Rural Banks: Do Financing Products Matter?," The Journal of Asian Finance, Economics, and Business 7, no. 9 (2020): 305.

${ }^{28}$ KM Anwarul Islam dan Orobah Ali Barghouthi, "Risk Management of Islamic Banking: An Islamic Perspective," International Journal of Islamic Banking and Finance Research 1, no. 1 (2017): 25-26.

29 Mohammad Obaidullah, "Islamic risk management," International Journal of Islamic Financial Services 3, no. 4 (2002): 295.

30 Daud Vicary Abdullah dan Keon Chee, Buku Pintar Keuangan Syariah, trans. oleh Satria Wahono (Jakarta: Zaman, 2012 ), 21. 
keuangan syariah meliputi pelarangan riba (memperanakkan uang dan mengharapkan hasil tanpa menanggung risiko), gharar dan maisir, objek dari seluruh proses investasi harus halal dan menjamin terlaksananya konsep kemaslahatan dari hulu sampai hilir dari proses investasi yang dilakukan. ${ }^{31}$ Sedangkan UU No. 21 Tahun 2008 tentang Perbankan Syariah menyatakan bahwa kegiatan usaha yang berasaskan prinsip syariah adalah kegiatan usaha yang tidak mengandung unsur riba, maisir, gharar, haram dan zalim. ${ }^{32}$ Prinsip syariah didefinisikan adalah prinsip hukum Islam dalam kegiatan perbankan berdasarkan fatwa yang dikeluarkan oleh lembaga yang memiliki kewenangan dalam penetapan fatwa di bidang syariah..$^{33}$ Dalam pasal lain mempertegas bahwa kegiatan usaha bank syariah wajib tunduk kepada prinsip syariah yang prinsip tersebut difatwakan oleh Majelis Ulama Indonesia. ${ }^{34}$

Pembiayaan berprinsip syariah menolak adanya bunga bank yang terkategorikan riba dan haram hukumnya dalam Islam. Hal tersebut menjadi perbedaan fundamental yang menjadikan karakter antara pembiayaan bank syariah berbeda dengan bank konvensional. Kredit di bank konvensional pada dasarnya mengaplikasikan akad qardh (utang-piutang/pinjaman uang) dalam kegiatan usaha penyaluran dananya yang sebenarnya merupakan akad yang bersifat sosial dan murni tolong, jadi tidak peruntukkan untuk mendapatkan profit, namun di bank konvensional praktik pembungaan uang digunakan sebagai penggerak roda bisnis dan ini merupakan transaksi ribawi yang diharamkan. sedangkan pembiayaan di bank syariah memiliki variasi akad syariah dengan beragam mekanisme khasnya masing-masing. Dalam pembiayaan syariah yang menjadi kegiatan usaha bank syariah, akad yang digunakan memang merupakan akad yang bersifat komersial dan diperuntukkan untuk mendapatkan profit atau menarik keuntungan, seperti akad jual beli atau bai' (murâbahah, salam dan istishna'), mudhârabah, musyârakah maupun ijaârah muntahiyyah bit tamlik. Hasil yang menjadi pendapatan bisa berbentuk margin (akad jual beli), bagi hasil (akad kerja sama) dan ujrah/fee/biaya sewa (akad ijârah/upah-mengupah/sewa-menyewa). Ketiga bentuk pembiayaan dan keuntungan yang didapatkan diakui eksistensinya dalam hukum ekonomi syariah sebagai operasional yang legal dan dihalalkan.

Berdasarkan tingkat kepastian dari hasil yang diperolehnya, akad komersial di bank syariah dapat diklasifikasikan menjadi dua kelompok, yaitu natural certainty contracts (NCC) dan natural uncertainty contracts (NUC). NCC adalah kontrak/akad yang memberikan kepastian pembayarannya, baik dari segi jumlah maupun waktu. Cash flow-nya bisa diprediksi dengan relatif pasti, karena sudah disepakati diawal oleh pihak-pihak yang berakad. Kontrak-kontrak ini menawarkan hasil (keuntungan) yang tetap dan pasti. Objek pertukarannyapun (baik barang atas jasa) harus ditetapkan diawal akad dengan pasti, baik jumlahnya, kualitasnya, harganya dan waktu penyerahannya. Akad yang termasuk dalam kelompok NCC adalah bai' (jual beli) dan ijârah (sewa-menyewa/upah-mengupah). Sedangkan NUC adalah kontrak/akad yang tidak memberikan kepastian pendapatan, baik dari segi jumlah maupun waktu. Tingkat hasil (keuntungan) bisa positif, negatif atau nol. Akad yang termasuk dalam kelompok natural uncertainty contracts adalah akad-akad investasi yang memang tidak menawarkan return yang tetap dan pasti seperti mudhârabah dan musyârakah. Maka dalam natural certainty contracts (NCC)

31 Muhammad Fauzan, Mengenal Lebih Dekat Perbankan Syariah dan Lembaga Lainnya Disertai Dengan Fatwa DSN-MUI (Makassar: Pena Indis, 2014), 1-2.

${ }^{32}$ Lihat Penjelasan Pasal 2 UU No. 21 Tahun 2008 tentang Perbankan Syariah

${ }^{33}$ Lihat Pasal 1 Angka 2 UU Perbankan Syariah.

${ }^{34}$ Lihat Pasal 26 Ayat (1) \& (2) UU Perbankan Syariah. 
berlaku teori pertukaran, sedangkan dalam natural uncertainty contracts berlaku teori percampuran. ${ }^{35}$

Bisnis memang tidak lepas dari risiko. Kredit bank konvensional dengan praktik pembungaan uangnya yang merupakan transaksi ribawi, dimana operasionalnya melegalkan bunga pinjaman yang sebenarnya termasuk penambahan keuntungan yang bathil karena termasuk ketegori riba qardh atau riba nasi'ah. Ketika manajemen risiko yang melekat pada pinjaman berbunga (transaksi ribawi) tadi diterapkan secara keseluruhan pada pembiayaan syariah, maka bisa jadi akan menjurus pada transaksi ribawi pula. Penerapan manajemen risiko pinjaman berbunga (transaksi ribawi) dalam setiap bagian yang melekat pada sistemnya ke dalam sistem manajemen risiko pembiayaan syariah seperti pembiayaan murâbahah, mudhârabah, musyârakah, maupun ijârah muntahiyyah bit tamlik yang jelas memiliki karakteristik akad dan konsekuensi hukum yang berbeda, hal ini memiliki potensi terjadinya pelanggaran prinsip syariah (ketidaksesuaian dengan yang seharusnya dijaga), karena operasional pembiayaan yang menjadi sandaran pengaplikasian manajemen risiko tadi melegalkan praktik pembungaan uang yang merupakan transaksi ribawi, maka manajemen risikonya bisa saja menjurus pada praktik ribawi pula. Seperti penerapan denda atau penalty di bank konvensional yang dapat masuk dalam kategori riba, sedangkan di bank syariah masalah denda sampai saat ini pun masih menuai pro dan kontra, dan DSN-MUI melalui fatwanya mendudukkan denda ini dalam sesuatu yang dibolehkan namun dengen syarat, karena itu DSN-MUI tidaklah membolehkannya secara mutlak, melainkan denda ini hanya boleh diterapkan sebagai sanksi atas nasabah mampu yang menundanunda pembayaran dengan beranjak pada prinsip ta'zir. Dananyapun tidak boleh dimasukkan kepada pendapatan, namun harus dimasukkan kepada dana sosial. ${ }^{36}$ Selain ta'zir, ada pula ta'widh (ganti rugi), dimana ta'zir dan ta'widh ini menjadi instrumen manajemen risiko dalam mengontrol moral hazard nasabah. ${ }^{37}$ Ta'widh memiliki perbedaan dengan ta'zir berupa denda, karena ta'widh tidak dibuat diawal kontrak melainkan dihitung pada waktu tertentu berdasarkan kerugian riil yang dialami pihak Bank. Peruntukkan dananya dijadikan sebagai pendapatan murni dari Bank. ${ }^{38}$ Baik itu ta'zir maupun ta'widh hanyalah salah satu bagian dari manajemen risiko dalam pembiayaan, sedangkan manajemen risiko itu sendiri cakupannya lebih luas daripada kedua instrumen tadi.

Eksistensi Bank Syariah sebagai salah satu lembaga keuangan syariah dengan telah memasuki era disrupsi dan terjadinya revolusi industri 4.0, maka haruslah dapat responsif dan dinamis dalam menyambut gelombang digitalisasi yang telah menyebar dan merubah tatanan perekonomian. Manajemen risiko pembiayaan 4.0 perbankan syariah perlu digalakkan dengan sistem pengendalian atau pengelolaan risiko yang diperkuat aspek digital, jadi antara aspek manajemen risiko dan aspek digital saling menguatkan atau bersinergi. Dengan hadirnya gelombang digitalisasi bukan dimaknai sebagai ancaman melainkan sebagai peluang dan spirit untuk bergerak dinamis. Dibalik upaya sistem manajemen risiko pembiayaan perbankan syariah yang memanfaatkan dengan optimal era disrupsi dan revolusi industri 4.0 yang terjadi sebagai sesuatu yang positif membawa pada perkembangan dan kemajuan, disisi lain perlu ditunjang dengan soliditas regulasi sebagai kekuatan hukum dan payung hukum yang menaungi, baik yang mengatur aspek teknis maupun aspek syariah, karena manajemen risiko pula merupakan kegiatan muamalah yang tidak lepas dari prinsip syariah yang

\footnotetext{
35 Adiwarman A. Karim, Bank Islam: Analisis Fiqih dan Keuangan (Jakarta: RajaGrafindo Persada, 2008).

${ }^{36}$ Lihat Fatwa DSN-MUI No. 17/DSN-MUI/XI/2000 tentang Sanksi atas Nasabah Mampu yang Menunda-nunda Pembayaran.

37 Firman Wahyudi, "Mengontrol Moral Hazard Nasabah Melalui Instrumen Ta'zir Dan Ta'widh," Al-Banjari : Jurnal Ilmiah IlmuIlmu Keislaman 16, no. 2 (15 November 2017): 193, https://doi.org/10.18592/al-banjari.v16i2.1357.

38 Lihat Fatwa DSN-MUI No. 43 Tahun 2004 tentang Ganti Rugi (Ta'widh).
} 
harus dipegang dalam pengaplikasiannya. Maka dalam hal ini DSN-MUI harus bersinergi dengan OJK sebagai regulator pengaturan lembaga keuangan, dan dalam hal ini DSN-MUI perlu membuat fatwa tentang pedoman manajemen risiko pembiayaan berbasis syariah, agar kesyariahan itu tidak parsial, hanya berada dalam teknis produk, tetapi tidak dipedulikan dalam teknis manajemen risiko pembiayaan yang dalam pengaplikasiannya tetap ada potensi menjurus kepada sesuatu yang pada dasarnya mengandung unsur terlarang atau dengan begitu melanggar prinsip syariah yang harusnya ditegakkan, apalagi yang diaplikasikan secara keseluruhan adalah manajemen risiko transaksi ribawi yang diberlakukan di Bank Konvensional.

Kedudukan fatwa dalam hukum Islam dikenal sebagai salah satu rujukan hukum yang dapat dipedomani. Pada awalnya fatwa diberikan secara perseorangan. Rasulullah saw. selalu memberikan jawaban terhadap pertanyaan-pertanyaan yang diajukan sahabat. Jawaban-jawaban yang diberikan Rasul menjadi landasan hukum dan bersifat mengikat bagi kaum muslimin sebagai aturan syari'ah. Akan tetapi setelah beliau wafat, permasalahan tentang hukum ditanyakan kepada khalifah yang mengantikan beliau atau para ulama kurun itu. Apabila mereka tidak mendapatkan pedoman dari Al Qur'an dan Sunnah maka mereka berijtihad. Ijtihad yang diberikan sebagai sebuah keputusan perorangan disebut dengan fatwa. Fatwa sebagai legal opini seorang ulama pada waktu itu tidaklah mengikat berbeda dengan masa Rasulullah. Tetapi ia merupakan informasi hukum bagi orang yang membutuhkannya. Sehingga terkadang bahkan sering, fatwa antara satu ulama dengan ulama lainnya terhadap satu masalah yang sama bisa berbeda. Perkembangan berikutnya fatwa tidak lagi diberikan secara persendirian tapi bergeser kepada institusi atau lembaga resmi yang di buat oleh lembaga pemerintahan untuk mendapat pertimbangan-pertimbangan dalam hukum Islam. ${ }^{39}$ Dalam hal ini, contoh fatwa yang dikeluarkan institusi atau lembaga yang ada di Indonesia adalah fatwa DSN-MUI. Sebagaimana hasil penelitian Yeni Salam Barlinti dalam Disertasinya yang berjudul fatwa DSN-MUI memiliki kekuatan hukum, bersifat mengikat karena eksistensinya dikuatkan dan dilegitimasi oleh pemerintah melalui peraturan perundang-undangan..$^{40}$

Perkembangan zaman terus bergerak dinamis dengan era globalisasi dan ilmu pengetahuan juga teknologi yang turut serta mengalami perkembangan pesat dalam berbagai sektor kehidupan masyarakat telah membawa pengaruh besar dalam lini perbincangan interaksi kehidupan termasuk hadirnya persoalan-persoalan baru yang tidak lepas dari aspek hukum. ${ }^{41}$ Fatwa merupakan jawaban terhadap problem dan permasalahan yang dihadapi oleh ummat Islam yang semakin hari semakin bertambah kompleks dan beragam. Fatwa merupakan jalan keluar yang memberikan jawaban keagamaan terhadap permasalahan yang muncul. ${ }^{42}$

Ijtihad dimaksimalkan fungsinya sebagai alat penggali hukum pada masa tabi'in, bahkan dipandang sebagai suatu kebutuhan yang harus dilakukan untuk bisa menjawab persoalanpersoalan baru yang belum ada ketetapan hukumnya. ${ }^{43}$ Berbedahalnya di masa sahabat, ijtihad

\footnotetext{
${ }^{39}$ Muhammad Yasir Yusuf, "Dinamika Fatwa Bunga Bank Di Indonesia: Kajian Terhadap Fatwa MUI, Muhammaddiyah Dan Nahdhatul Ulama," Media Syari'ah: Wahana Kajian Hukum Islam Dan Pranata Sosial 14, no. 2 (30 Oktober 2012): 155-56, https:// doi.org/10.22373/jms.v14i2.1872.

40 Yeni Salma Barlinti, "Kedudukan Fatwa Dewan Syariah Nasional Dalam Sistem Hukum Nasional di Indonesia," Universitas Indonesia: Fakultas Hukum, Program Doktoral Pascasarjana, Disertasi, 2010, 470.

41 Rusdaya Basri, "Ibnu Qayyim al-Jawziyyah tentang Pengaruh Perubahan Sosial," Al-Manahij: Jurnal Kajian Hukum Islam 9, no. 2 (2015): 194, https://doi.org/10.24090/mnh.v9i2.489.

42 Rodliyah, Nargis, dan Husen, "Kedudukan Fatwa Terhadap Dasar Hukum Penyelesaian Sengketa Ekonomi Syariah Melalui BASYARNAS," 10.

43 Mami Nofrianti, “Perkembangan Hukum Islam Pada Masa Umar Ibn Khattab (634-644 M)," JURIS (Jurnal Ilmiah Syariah) 17, no.
} 
belum bisa disebut sebagai alat penggali hukum, oleh karena saat itu di masa Rasulullah SAW masih hidup, setiap persoalan yang dihadapi sahabat dan mereka mengalami kebingungan maupun keraguraguan akan suatu kasus hukum, maka dapat bertanya langsung kepada Rasulullah SAW untuk meminta jawabannya.

Sedangkan melihat situasi dan kondisi saat ini, dimana derasnya arus perkembangan zaman dan pesatnya kemajuan teknologi serta peralihan dan pergeseran perilaku sosial dalam interaksi yang kompleks, maka mempengaruhi berbagai sektor kehidupan yang pada akhirnya melahirkan kasuskasus baru yang menjadi persoalan yang dihadapi dan sangat penting untuk mendapatkan status hukum agar memberikan kepastian hukum akan eksistensinya di masyarakat. Maka dengan begitu, ijtihad menduduki posisi yang sentral dalam merespons hal tersebut, agar umat tidak kebingungan dan dilanda rasa keragu-raguan dalam menghadapi persoalan kekinian yang begitu beragam dengan mendapatkan jawaban untuk memecahkan masalah hukum yang terjadi, termasuk masalah ekonomi dan keuangan yang terus bergerak dinamis dengan beragam produk dan mekanisme serta pembaruan.

Kedudukan fatwa dalam konstruksi hukum Islam mempunyai kedudukan yang tinggi. Fatwa dipandang sebagai solusi yang bisa memecahkan kebekuan dalam perkembangan hukum yang tidak terakomodasi dengan nash-nash. fatwa menjadi solusi dalam mengurai problematika yang dihadapi umat yang berorientasi kepada kemaslahatan. ${ }^{44}$

Komprehensifnya ajaran Islam telah menunjukkan syariat Islam sebagai hukum yang mengatur habluminallah dan habluminannâs serta alam sekitar dalam kehidupan dengan muatan ibadah dan muamalah. ${ }^{45}$ Syariat tidak lepas dari maslahat, begitupun sebaliknya maslahat tidak lepas dari syariat.

Kaidah terkait adalah sebagai berikut:46

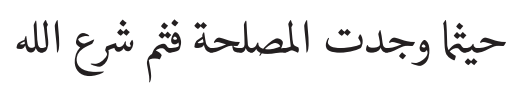

"Di mana terwujud kemaslahatan, disana terdapat hukum Allah"

Tujuan Allah SWT mensyariatkan hukumnya adalah untuk memelihara kemaslahatan manusia sekaligus untuk menghindari mafsadat, baik di dunia maupun di akhirat. Tujuan tersebut hendak dicapai melalui taklifyang pelaksanaannya tergantung pada penalaran sumber hukum utama yaitu alQuran dan Hadits ${ }^{47}$. Oleh karena itu, asy-Syâtibî menegaskan bahwa kemaslahatan tidak diukur oleh hawa nafsu, karena jika sesuatu itu mengandung kemaslahatan dunia tanpa kemaslahatan akhirat, maka itu bukan maslahat. Jadi tolak ukur dari maslahat adalah kembali kepada al-Qur'an dan sunnah sebagai mashâdir al-Ahkâm al-Syar'iyyah, tidak hanya disandarkan kepada akal saja, melainkan akal haruslah didasarkan dan diarahkan oleh syariat, bukan diarahkan bebas tanpa arah apalagi dibangun oleh hawa nafsu belaka. Tujuan disyariatkannya hukum adalah untuk kemaslahatan, maka antara syariat dan maslahat tidak dapat dipisahkan, satu sama lain terhubung dalam bingkai hukum Islam.

2 (31 Desember 2018): 269-82, https://doi.org/10.31958/juris.v17i2.1173.

44 Ibnu Elmi Achmat Slamat Pelu dan Jefry Tarantang, "Fatwa Majelis Ulama Indonesia Sebagai Solusi Permasalahan Umat Islam Di Indonesia," Al-Manahij: Jurnal Kajian Hukum Islam 14, no. 2 (3 Desember 2020): 315, https://doi.org/10.24090/mnh. v14i2.3927.

45 Yûsuf al Qaradhâwî, Fiqih Maqashid Syariah: Moderasi Islam antara Aliran Tekstual dan Liberal, trans. oleh Arif Munandar Riswanto (Jakarta: Pustaka al-Kautsar, 2006); Muhammad Syaltût, al-Islâm: 'Aqîdah wa Syarî'ah (Kairo: Dâr al-Qalam, 1996).

46 Muhammad al Amîn bin Muhammad al Mukhtâr bin 'Abd al Qâdir al Jaknî asy Syinqîthî, al-Mashâlih al-Mursalah (Madinah: al-Jâmi'ah al-Islâmiyyah, 1990); Wahbah az Zuhailî, al-Fiqh al-Islâmî wa Adillatuh, vol. 1 (Damaskus: Dâr al-Fikr, 1985).

47 Fathurrahman Djamil, Filsafat Hukum Islam (Jakarta: Logos Wacana Ilmu, 1997), 125. 
Karena itu tolak ukur dan pedoman maslahat kembali pada syariat, sesuatu yang tidak bertentangan dengan syariat.

Kaidah terkait adalah sebagai berikut:48

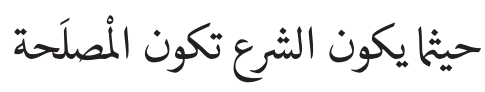

"Apabila hukum syara' dilaksanakan, maka pastilah tercipta kemaslahatan."

Eksistensi fatwa di tengah masyarakat dalam rangka menjawab persoalan yang dihadapi umat terutama pada kasus-kasus kontemporer memiliki urgensi dan signifikansi yang dapat dilihat pada fungsi yang dijalankan sebagai mediasi antara idealitas hukum Islam di satu sisi dan realitas faktual disisi lain. ${ }^{49}$

Sebagaimana dikatakan oleh Ibnu Qayyim al-Jauziyyah:

$$
\text { تغير الفتوى بتغير الأزمنة والأحوال }
$$

"Perubahan Fatwa itu berdasarkan perubahan zaman dan keadaan"

Kemudian dalam redaksi kaidah ushul lainnya:

$$
\text { تغير الفتوى واختلافها بحسب تغير الأزمنة والأمكنة والأحوال والنيات، والحكمة منهـ51 }
$$

"Perubahan dan Perbedaan fatwa sesuai dengan perubahan zaman, tempat, keadaan, niat, dan hikmahnya."

Fatwa DSN-MUI bagi lembaga keuangan syariah memiliki empat fungsi. Pertama, sebagai pedoman operasional dan produk-produk lembaga keuangan syariah. kedua, sebagai dasar dan acuan untuk pengembangan produk. Ketiga, sebagai pedoman kesesuaian syariah operasional dan produk lembaga keuangan syariah. keempat, sebagai pedoman dasar bagi DPS untuk mengawasi kesesuaian syariah di LKS yang diawasi. ${ }^{52}$

Oleh sebab itu, pembiayaan syariah dengan karakteristik dan konsekuensi hukum yang berbeda dengan kreditkonvensional, apalagi dengan variasi dankekhasan mekanismenya serta harus terhindar daripada unsur terlarang terutama riba, maka dengan demikian menjadi pentinglah perumusan pedoman manajemen risiko berbasis syariah yang bebas dari unsur terlarang dalam muamalah. Menjadi langkah yang urgen, agar dirumuskannya Fatwa DSN-MUI yang substansinya mengenai pedoman manajemen risiko pembiayaan berbasis syariah yang isinya dapat mencakup prinsipprinsip dasar manajemen risiko berbasis syariah, koridor syariah yang tidak boleh dilanggar dalam proses manajemen risiko termasuk rambu-rambu syariah dalam kegiatan rescheduling, reconditioning maupun restructuring, unsur-unsur yang terlarang dipraktikkan dalam upaya manajemen risiko dan

\footnotetext{
48 Muhammad Muhammad Ismâ'̂̂l, al-Fikr al-Islâm (Beirut: al-Maktabah al-Wa'̂̂, 1958), 43.

49 Irma Suryani, “Metode Fatwa Majelis Ulama Indonesia,” JURIS (Jurnal Ilmiah Syariah) 9, no. 2 (23 Februari 2018): 176, https:// doi.org/10.31958/juris.v9i2.915.

50 Muhammad bin Abû Bakr bin Qayyim al Jauziyyah, I'lâm al-Muwaqqi'în 'an Rabb al-âlamîn, vol. 3 (Kairo: Maktabah al-Kulliyât al-Azhariyah, 1968), 38.

${ }^{51}$ Muhammad bin Husain bin Hasan al Jaizânî, Ma'âlim Ushûl al-Fiqh 'Ind Ahl as-Sunnah wa al-Jamâ'ah (Mesir: Dâr Ibn al-Jauzî, 1427), 547.

52 Akhmad Faozan, "Pola dan Urgensi Positivisasi Fatwa-Fatwa Dewan Syariah Nasional Majelis Ulama Indonesia tentang Perbankan Syariah di Indonesia," Al-Manahij: Jurnal Kajian Hukum Islam 10, no. 2 (2016): 315, https://doi.org/10.24090/mnh. v10i2.941.
} 
lain sebagainya. Dengan begitu tercipta sinergi antara BI, OJK dan DSN-MUI. Selain itupula perlu juga mensinergikan dengan stakeholder lain seperti Komite Nasional Keuangan Syariah (KNKS) sebagai badan yang bertugas dalam merealisasikan MEKSI 2019-2024 serta juga kepada organisasi penggerak ekonomi syariah semisal Masyarakat Ekonomi Syariah (MES), Ikatan Ahli Ekonomi Islam (IAEI), Asosiasi Bank Syariah Indonesia (Asbisindo) dan organisasi-organisasi gerakan ekonomi syariah lainnya.

\section{Penutup}

Bank Syariah harus mampu beradaptasi dengan memberlakukan sistem yang dinamis di era disrupsi dan masuknya kita pada revolusi industri 4.0 ini. Selain dinamisasi sistem, sangat penting pula memperkuat aspek yuridis agar memberikan kekuatan hukum dengan terwujudnya soliditas regulasi. Dengan prinsip syariah sebagai dasar operasional Bank Syariah, maka manajemen risiko pembiayan yang juga merupakan bagian dari muamalah haruslah tetap memperhatikan prinsip syariah di dalamnya, karena itu selain aturan yang dikeluarkan OJK, fatwa DSN-MUI pula diperlukan untuk menjaga tegaknya prinsip syariah dalam upaya manajemen risiko tersebut yang menjadi bagian tidak terpisahkan dalam operasional pembiayaan syariah. Jangan sampai kesyariahan hanya ada pada teknis akad produk, tetapi tidak dilakukan pada teknis pengelolaan risikonya. Oleh sebab itu merupakan sesuatu yang urgen untuk DSN-MUI dapat mengeluarkan pedoman manajemen risiko pembiayaan berbasis. Apabila yang diaplikasikan secara keseluruhan dalam manajemen risiko pembiayaan bank syariah adalah manajemen risiko pinjaman ribawi yang diberlakukan di Bank Konvensional, padahal pembiayaan syariah memiliki karakteristik yang berbeda dengan tidak memberlakukan akad qardh yang termasuk akad tabarru dalam pembiayaan bersifat komersial, melainkan hanya menerapkan akad tijârah (di antaranya: murâbahah, musyârakah, IMBT), maka dengan begitu muncul potensi menjurus kepada transaksi ribawi pula atau kepada sesuatu yang pada dasarnya mengandung unsur terlarang sehingga terjadi pelanggaran prinsip syariah.

\section{Daftar Pustaka}

Abdullah, Daud Vicary, dan Keon Chee. Buku Pintar Keuangan Syariah. Diterjemahkan oleh Satria Wahono. Jakarta: Zaman, 2012.

Azhari, Fathurrahman. Qawaid Fiqhiyyah Muamalah. Banjarmasin: Lembaga Pengembangan Kualitas Umat, 2014.

Basri, Rusdaya. “Ibnu Qayyim al-Jawziyyah tentang Pengaruh Perubahan Sosial.” Al-Manahij: Jurnal Kajian Hukum Islam 9, no. 2 (2015): 193-206. https://doi.org/10.24090/mnh.v9i2.489.

Bugha, Musthafa Dib al-. Kompilasi Hukum Islam ala Madzhab Syafi'i. Surabaya: al-Hidayah, 2009.

Djamil, Fathurrahman. Filsafat Hukum Islam. Jakarta: Logos Wacana Ilmu, 1997.

Faozan, Akhmad. "Pola dan Urgensi Positivisasi Fatwa-Fatwa Dewan Syariah Nasional Majelis Ulama Indonesia tentang Perbankan Syariah di Indonesia.” Al-Manahij: Jurnal Kajian Hukum Islam 10, no. 2 (2016): 309-21. https://doi.org/10.24090/mnh.v10i2.941.

Fauzan, Muhammad. Mengenal Lebih Dekat Perbankan Syariah dan Lembaga Lainnya Disertai Dengan Fatwa DSN-MUI. Makassar: Pena Indis, 2014. 
Gandapradja, Permadi. Dasar dan Prinsip Pengawasan Bank. Jakarta: Gramedia Pustaka Utama, 2004. Hafidah, Noor. Hukum Jaminan Syariah \& implementasinya dalam perbankan syariah di indonesia. Yogyakarta: UII Press, 2017.

Handoko, T. Hani. Manajemen. Yogyakarta: BPFE-Yogyakarta, 2003.

Hardiani, Isriani, dan Muh. H. Giharto. Kamus Perbankan Syariah. Bandung: Marja, 2007.

Hidayatullah, Muhammad Syarif. "Islamic Economics And Partial-Total Religiosity: A Case Study Of Majlis Taklim In Banjarmasin.” Islamuna: Jurnal Studi Islam 7, no. 1 (12 Juni 2020): 36-55. https:// doi.org/10.19105/islamuna.v7i1.3308.

--- Perbankan Syariah: Pengenalan Fundamental dan Pengembangan Kontemporer. Banjarbaru: Dreamedia, 2017.

Ikatan Bankir Indonesia. Mengelola Bisnis Pembiayaan Bank Syariah. Jakarta: Gramedia Pustaka Utama, 2015.

Islam, KM Anwarul, dan Orobah Ali Barghouthi. "Risk Management of Islamic Banking: An Islamic Perspective." International Journal of Islamic Banking and Finance Research 1, no. 1 (2017): 25-28.

Ismâ'îl, Muhammad Muhammad. al-Fikr al-Islâm. Beirut: al-Maktabah al-Wa'̂̂, 1958.

Jaizânî, Muhammad bin Husain bin Hasan al. Ma'âlim Ushûl al-Figh 'Ind Ahl as-Sunnah wa al-Jamâ'ah. Mesir: Dâr Ibn al-Jauzî, 1427.

Jalagat, Revenio. "The impact of change and change management in achieving corporate goals and objectives: Organizational perspective." International Journal of Science and Research 5, no. 11 (2016): 1233-39.

Jauziyyah, Muhammad bin Abû Bakr bin Qayyim al. I'lâm al-Muwaqqi'în 'an Rabb al-âlamîn. Vol. 1. Kairo: Maktabah al-Kulliyât al-Azhariyah, 1968.

Karim, Adiwarman A. Bank Islam: Analisis Fiqih dan Keuangan. Jakarta: RajaGrafindo Persada, 2008.

Laela, Sugiyarti Fatma. "Kualitas Laba dan Corporate Governance: Benarkah Kualitas Laba Bank Syariah Lebih Rendah dari Bank Konvensional?" Jurnal Akuntansi dan Keuangan Indonesia 9, no. 1 (2014): 22-42.

Nawawi, Ismail. Fikih Muamalah Klasik dan Kontemporer. Bogor: Ghalia Indonesia, 2012.

Nofrianti, Mami. "Perkembangan Hukum Islam Pada Masa Umar Ibn Khattab (634-644 M)." JURIS (Jurnal Ilmiah Syariah) 17, no. 2 (31 Desember 2018): 269-82. https://doi.org/10.31958/juris. v17i2.1173.

Obaidullah, Mohammad. "Islamic risk management." International Journal of Islamic Financial Services 3, no. 4 (2002): 291-311.

Pelu, Ibnu Elmi Achmat Slamat, dan Jefry Tarantang. "Fatwa Majelis Ulama Indonesia Sebagai Solusi Permasalahan Umat Islam Di Indonesia.” Al-Manahij: Jurnal Kajian Hukum Islam 14, no. 2 (3 Desember 2020): 307-16. https://doi.org/10.24090/mnh.v14i2.3927.

Qaradhâwî, Yûsuf al. Fiqih Maqashid Syariah: Moderasi Islam antara Aliran Tekstual dan Liberal. Diterjemahkan oleh Arif Munandar Riswanto. Jakarta: Pustaka al-Kautsar, 2006.

Ramlan, Sitti Ruwaida, Silcyljeova Moniharapon, dan Joy Elly Tulung. “Analisis Perbandingan Risiko Kredit Antara Bank Syariah Dan Bank Konvensional.” Jurnal EMBA: Jurnal Riset Ekonomi, 
Manajemen, Bisnis dan Akuntansi 6, no. 1 (26 Februari 2018). https://doi.org/10.35794/emba. v6i1.19019.

Rivai, Veithzal, dan Andria Permata Veithzal. Islamic Financial Manaement: Teori, Konsep dan Aplikasi Panduan Praktis untuk Lembaga Keuangan, Nasabah, Praktisi, dan Mahasiswa. Jakarta: RajaGrafindo Persada, 2008.

Rodliyah, Nunung, Nila Nargis, dan Abdur Rohman Husen. "Kedudukan Fatwa Terhadap Dasar Hukum Penyelesaian Sengketa Ekonomi Syariah Melalui BASYARNAS.” Nizham Journal of Islamic Studies 7, no. 01 (12 Juli 2019): 1-16.

Roghanian, Parastoo, Amran Rasli, dan Hamed Gheysari. "Productivity through effectiveness and efficiency in the banking industry." Procedia-Social and Behavioral Sciences 40 (2012): 550-56.

Salma Barlinti, Yeni. "Kedudukan Fatwa Dewan Syariah Nasional Dalam Sistem Hukum Nasional di Indonesia." Universitas Indonesia: Fakultas Hukum, Program Doktoral Pascasarjana, Disertasi, 2010.

Sovia, Sasa Elida, Muhammad Saifi, dan Achmad Husaini. “Analisis Perbandingan Kinerja Keuangan Bank Konvensional Dan Bank Syariah Berdasarkan Rasio Keuangan Bank (Studi pada Bank Konvensional yang Terdaftar di BEI yang Memiliki Bank Syariah Periode 2012-2014)." Jurnal Administrasi Bisnis 37, no. 1 (2016): 129-36.

Suryani, Irma. "Metode Fatwa Majelis Ulama Indonesia." JURIS (Jurnal Ilmiah Syariah) 9, no. 2 (23 Februari 2018): 175-84. https://doi.org/10.31958/juris.v9i2.915.

Syaltût, Muhammad. al-Islâm: 'Aqî̉ah wa Syarîah. Kairo: Dâr al-Qalam, 1996.

Syinqîthî, Muhammad al Amîn bin Muhammad al Mukhtâr bin 'Abd al Qâdir al Jaknî asy. al-Mashâlih al-Mursalah. Madinah: al-Jâmi'ah al-Islâmiyyah, 1990.

Wahyudi, Firman. "Mengontrol Moral Hazard Nasabah Melalui Instrumen Ta'zir Dan Ta'widh.” AlBanjari: Jurnal Ilmiah Ilmu-Ilmu Keislaman 16, no. 2 (15 November 2017): 186-202. https://doi. org/10.18592/al-banjari.v16i2.1357.

Widarjono, Agus, MB ANTO, dan Faaza Fakhrunnas. "Financing Risk in Indonesian Islamic Rural Banks: Do Financing Products Matter?" The Journal of Asian Finance, Economics, and Business 7, no. 9 (2020): 305-14.

Wirdyaningsih, Karnaen Perwataadmadja, Gemala Dewi, dan Yeni Salam Barlinti. Bank dan Asuransi Islam di Indonesia. Jakarta: Kencana Prenada Media, 2005.

Yusuf, Muhammad Yasir. "Dinamika Fatwa Bunga Bank Di Indonesia: Kajian Terhadap Fatwa MUI, Muhammaddiyah Dan Nahdhatul Ulama." Media Syari'ah: Wahana Kajian Hukum Islam Dan Pranata Sosial 14, no. 2 (30 Oktober 2012): 151-60. https://doi.org/10.22373/jms.v14i2.1872.

Zuhailî, Wahbah az. al-Fiqh al-Islâmî wa Adillatuh. Vol. 1. Damaskus: Dâr al-Fikr, 1985. 